\title{
FERRAMENTAS PARA O PLANEJAMENTO DE ENSINO: FOCO NA TRANSPOSIÇÃO DIDÁTICA EXTERNA DE GÊNEROS TEXTUAIS
}

\author{
TOOLS FOR THE TEACHING PLANNING: FOCUS ON THE \\ EXTERNAL DIDACTIC TRANSPOSITION OF TEXTUAL GENRES
}

Eliana Merlin Deganutti de Barros ${ }^{1}$

Gabriela Martins Mafra²

\begin{abstract}
RESUMO: Este artigo coloca em evidência três ferramentas didáticas mediadoras do planejamento e da planificaçăo de atividades voltadas para a didatizaçăo de gêneros textuais: 1) o modelo teórico do gênero, 2) o modelo didático, 3) a sinopse da sequência didática de gêneros. 0 objetivo da investigaçáo é mostrar a articulaçăo entre essas ferramentas e sua importância no processo de transposiçăo didática externa. Os dados da pesquisa săo gerados no contexto do subprojeto PIBID "Letramentos na escola: práticas de leitura e produçâo textual", desenvolvido na Universidade Estadual do Norte do Paraná (UENP - campus Cornélio Procópio). O aporte teórico-metodológico que sustenta tanto as açóes do subprojeto como a pesquisa săo os estudos desenvolvidos pelo Interacionismo Sociodiscursivo (ISD), principalmente, em sua vertente didática. Neste trabalho, analisa-se especificamente o papel das três ferramentas na didatizaçâo do gênero "carta do leitor", no interior de um projeto de ensino voltado para a elaboraçâo de um jornal escolar (Jornal PIBID - Primeira Ediçăo). Esperamos, assim, estimular reflexóes em relaçăo à importância de investigaçóes que se debrucem em questôes ligadas à transposiçăo didática externa de gêneros textuais, dando, assim, relevância à etapa do planejamento escolar.
\end{abstract}

Palavras-chave: Ferramentas didáticas; Carta do leitor.

ABSTRACT: This article puts in evidence three didactic mediator tools of the planning and the planning of the activities focused on the didactization of textual genres: 1) the theoretical model of genre, 2) the didactic model, 3) the synopsis of the genre didactic sequence. The objective of the investigation is to show the articulation between these tools and their importance on the external didactic transposition process. The research data are generated in the context of the subproject PIBID "Letramento na escola: práticas de leitura e produçâo textual", developed in the Universidade Estadual do

1 Doutorado em estudos da Linguagem (UEL). Professora adjunta da Universidade Estadual do Norte do Paraná (UENP), campus de Cornélio Procópio - Curso de Letras e Programa de Mestrado Profissional em Letras em Rede (PROFLETRAS). Líder do GP-CNPq DIALE - Diálogos Linguísticos e Ensino. E-mail: edeganutti@hotmail.com

2 Graduada em Letras Português-Inglês (UENP). Professora da rede municipal de Cornélio Procópio. Colaboradora do GP DIALE.E-mail: gabi_martins_mafra@hotmail.com 
Norte do Paraná (UENP - campus Cornélio Procópio). The theoretical-methodological contribution that supports both the subproject actions and the research are the studies developed by the Sociodiscursive Interactionism (ISD), mainly, in its didactic aspect. It"s specifically analyzed in this project the role of the three tools in the didactization of the genre "reader's letter", in the interior of a teaching project focused for the elaboration of a scholar newspaper (The newspaper PIBID - First edition). We hope, therefore, stimulate reflections in relation to the importance of investigations that consider in questions connected to the external didactic of textual genres, thereby, giving relevance to the scholar education process.

Keywords: ISD; Didactic tools; Reader's letter.

\section{INTRODUÇÃO}

Este trabalho justifica-se por discutir práticas, muitas vezes, esquecidas pelo sistema de ensino, como o planejamento didático - o que inclui a modelizaçăo dos objetos de ensino. Essa prática é essencial quando pensamos no projeto educativo da escola (BRASIL, 1998). Segundo Rojo (2001), o planejamento educacional prevê uma seleçâo e organizaçấo de "conteúdos", os quais devem ser tema de açōes didáticas distribuídas no tempo e espaço escolar. O planejamento influencia diretamente as açôes didáticas, sendo assim, ele deveria ser incorporado no dia a dia da profissáo docente, pois o resultado do processo de ensino-aprendizagem está diretamente relacionado com atitudes e açóes que săo mobilizadas antes de se entrar em sala de aula.

Rojo (2001, p. 315) relata que em seus encontros com professores da rede pública se depara com docentes preocupados "em melhorar sua açăo didática e em programar novas e melhores orientaçóes no processo de ensino-aprendizagem". No entanto, esse professorado está "quase sempre sem condiçōes objetivas para fazê-lo - por exemplo, tempo escolar remunerado e reservado ao planejamento e à reflexăo coletivos - e pouco formado para fazê-lo" (p. 316). Entendemos, assim como a autora, que é preciso dar condiçôes (formaçấo e estrutura) para que os nossos docentes possam ser atores-produtores conscientes das suas açôes didáticas, o que inclui, evidentemente, momentos de planejamento.

Comungamos da ideia de que um professor para conseguir ser "planejador das práticas escolares" precisa de condiçôes favoráveis que possibilitem essa açâo, além de formaçăo adequada para esse fim, pois, muitas vezes, falta ao professor estratégias (tanto teóricas, metodológicas ou de gestăo) para pensar no seu agir docente. Muitas vezes, ele se restringe ao que o livro didático lhe oferece.

Pensando no ensino de Língua Portuguesa por meio dos gêneros textuais, uma das ferramentas didáticas que podem auxiliar o professor em seu planejamento é a modelizaçăo didática idealizada pelo Interacionismo Sociodiscursivo (ISD), que prevê: 1) conhecimento das prescriçôes oficiais de ensino (desde as diretrizes nacionais até o projeto político pedagógico da escola); 2) seleçâo dos objetos de ensino (gêneros a serem trabalhados); 3) consultas à literatura especializada em relaçâo a tais objetos sociais de referência; 4) análises contextuais e linguístico-discursivas de um determinado corpus de textos; 5) análise do contexto de intervençâo didática. Essa ferramenta possibilita que o professor conheça o potencial do objeto de ensino e possa, assim, fazer escolhas direcionadas ao processo de didatizaçăo. 
Cristovăo (2005, p. 155) defende que, ao realizar esse procedimento, o "professor está se corresponsabilizando pelo desenvolvimento de competências relacionadas às atividades do professor, pois o trabalho do professor năo se resume a dar aula ou a seguir as prescriçōes oficiais", mas a encarar sua profissăo como um "processo contínuo de reelaboraçăo das normas oficiais, que começa pelo projeto da escola e por suas próprias reorganizaçôes, diante do contexto a que se vê confrontado". Ainda segundo Cristovăo (2005, p. 156), a prática de ensino deve "proporcionar as condiçóes para que o sujeito aprenda a analisar o discurso oficial, analisar o contexto de ensino, elaborar um projeto pedagógico, planejar unidades de ensino e atividades etc.". Todas essas açôes estăo a favor do que os pesquisadores de Genebra filiados ao ISD denominam de transposiçâo didática externa ou seja, a passagem dos saberes teóricos aos saberes a ensinar.

Pretendemos, neste trabalho, náo apenas ressaltar a relevância da modelizaçáo para o planejamento, mas mostrar um estudo de caso realizado no interior de um subprojeto PIBID (Programa Institucional de Bolsas de Iniciaçaáo à Docência), desenvolvido na Universidade Estadual do Norte do Paraná (UENP - campus de Cornélio Procópio), com professores em formaçăo inicial, a fim de discutir a importância dessas práticas na didatizaçâo da "carta do leitor", um dos gêneros publicados no Jornal PIBID - Primeira Ediçâo (2014) - , fruto das intervençōes didáticas do subprojeto.

Para estruturar o artigo, trazemos: 1) "A transposiçăo didática na engenharia do ISD" para discutir a importância da didatizaçáo dos conhecimentos no processo de ensino-aprendizagem; 2) "A modelizaçâo do objeto de ensino", tópico no qual apresentamos e esclarecemos o funcionamento de duas ferramentas de ensino: o modelo teórico e o modelo didático do gênero; 3) "Sequência didática de gêneros", cujo objetivo é apresentar o procedimento didático criado pelo ISD para o domínio de uma prática de linguagem configurada em um gênero textual; 4) "O contexto da intervençấo didática: PIBID", no qual trazemos à tona o subprojeto PIBID de Língua Portuguesa que deu origem aos dados da pesquisa; 5) "O processo de modelizaçăo e didatizaçăo do gênero "carta do leitor"'", que traz resultados das análises, colocando em evidência três etapas da transposiçấo didática externa - a) a modelizaçâo teórica do objeto de ensino; b) a modelizaçâo didática; c) a transformaçâo dos saberes do gênero em atividades de uma SDG, explicitadas pela ferramenta "sinopse da sequência didática da carta do leitor" - e a articulaçăo essencial entre ambas. O objetivo é mostrar a importância dessas ferramentas no planejamento do trabalho didático, na perspectiva assumida pelo interacionismo instrumental adotada pelo ISD.

\section{A TRANSPOSIÇÃO DIDÁTICA NA ENGENHARIA DO ISD}

Segundo Chevallard (1991), os conhecimentos, antes de chegarem à sala de aula, devem receber transformaçóes para que se tornem objetos ensinados e aprendidos. Esse processo de transformaçấo dos conhecimentos teóricos em conhecimentos didáticos vem sendo nomeado pela literatura especializada de transposiçâo didática.

Como sabemos, para que a transposiçâo didática se efetive, várias açōes e, consequentemente, decisôes e escolhas, devem ser tomadas nos três níveis da atividade educacional - sistema educacional, sistema de ensino e sistema didático (Cf.: Quadro 1) - em relaçăo aos saberes de referência, objetos e ferramentas de ensino, metodologias, concepçôes teóricas, etc. Essas escolhas têm um "efeito cascata", agindo do nível mais geral - sistema 
educacional - para o mais localizado - sistema didático -; o que gera, evidentemente, tensôes que acabam, muitas vezes, influenciando novas decisóes e reformulaçôes. Assim, năo é possível imputar ao sistema educacional - onde residem os mecanismos federais e estaduais da organizaçăo formal de ensino - o papel de "juiz da sentença educacional". Todos os níveis, com suas deliberaçôes, sâo importantes para que os vários processos de transposiçôes didáticas atinjam seu objetivo maior: o aprendizado do aluno.

Quadro 1 - Os três níveis da atividade educacional

\begin{tabular}{|c|c|c|}
\hline 1. ${ }^{\circ}$ NÍVEL & 2. ${ }^{\circ}$ NÍVEL & 3. ${ }^{\circ}$ NÍVEL \\
\hline SISTEMA EDUCACIONAL & SISTEMA DE ENSINO & SISTEMA DIDÁTICO \\
\hline $\begin{array}{c}\text { Este nível é responsável } \\
\text { pela formulação de diretrizes } \\
\text { educacionais gerais. No contexto } \\
\text { brasileiro, podemos citar } \\
\text { documentos como os Parâmetros } \\
\text { Curriculares Nacionais (PCN), as } \\
\text { Diretrizes Curriculares Estaduais, a } \\
\text { Base Nacional Comum Curricular, } \\
\text { além das Matrizes Curriculares das } \\
\text { quais se originam as diretrizes para a } \\
\text { organização dos saberes implicados } \\
\text { na Prova Brasil e Provinha Brasil. }\end{array}$ & $\begin{array}{l}\text { Aqui se situam as escolas, os } \\
\text { programas, a administração, } \\
\text { supervisão e coordenação das } \\
\text { ações no interior da escola, tanto } \\
\text { para a organização do tempo } \\
\text { (séries, anos, ciclos do fluxo } \\
\text { escolar) como para a progressão } \\
\text { das aprendizagens. }\end{array}$ & $\begin{array}{c}\text { Nesse nível se localizam os três } \\
\text { polos: professor/alunos/objetos do } \\
\text { conhecimento. } \\
\text { Nele se institucionalizam, } \\
\text { presentificam e focalizam os objetos } \\
\text { do conhecimento e se materializam } \\
\text { os mecanismos de internalização e } \\
\text { apropriação dos artefatos culturais } \\
\text { por meio dos gestos didáticos dos } \\
\text { professores. }\end{array}$ \\
\hline
\end{tabular}

Fonte: adaptado de Nascimento (2011, p. 430)

Essa teoria da transposiçăo didática vem sendo explorada pelos estudiosos do Interacionismo Sociodiscursivo (ISD) para compreender a dinâmica da didatizaçáo dos saberes em ambiente de ensino e aprendizagem da língua. Para tanto, tais estudiosos subdividem o processo geral da transposiçâo didática em dois focos. Um diz respeito à transposiçâo didática externa (objeto da nossa pesquisa), etapa na qual o objeto teórico é transformado em objeto a ser ensinado; o outro comporta a transposiçâo didática interna, na qual os conhecimentos passam a ser efetivamente ensinados e aprendidos (DOLZ; GAGNON; CANELAS-TREVISI, 2009; BARROS, 2012a).

Existe uma visâo simplista em relaçâo ao trabalho docente, como se ele somente se localizasse no âmbito da transposiçăo didática interna ("dentro da sala de aula"). Precisamos valorizar e incentivar as formaçōes que focalizam também a transposiçâo didática externa, momento de se pensar nas primeiras transformaçôes pelas quais passa o conhecimento, de buscar compreender como os objetos de referência funcionam e como eles podem ser adaptados para o contexto do sistema didático; momento também de se planejar as açôes docentes. É justamente esse o foco do nosso artigo.

Em uma visáo interacionista de ensino da língua, tendo como eixo estruturador os gêneros textuais, precisamos de ferramentas para mediar o processo de transposiçấo didática dos conhecimentos integrantes das práticas de linguagem. Os pesquisadores de Genebra propóem duas ferramentas: o modelo didático e a sequência didática de gêneros (SDG), ${ }^{3}$ as quais exploramos a seguir.

3 O gênero textual é o objeto unificador da sequência didática, por isso optamos por acrescentar "de gêneros" à expressăo "sequência didática". Dessa forma, distinguimos o procedimento criado pelo ISD de outros, os quais pertencem a áreas diferentes, que levam a mesma designaçăo. 


\section{A MODELIZAÇÃO DO OBJETO DE ENSINO}

Para De Pietro e Schneuwly (2014), o modelo didático é um conceito que tem origem na prática da engenharia didática e que possibilita estabilizá-la, tornando-a visível e sistematizando-a. É uma ferramenta que permite visualizar as "dimensôes ensináveis do gênero" (Cf.: DE PIETRO; SCHNEUWLY, 2014), ou seja, cria um parâmetro para o ensino do objeto, dando condiçóes ao professor de planejar as atividades para a sua didatizaçăo.

Segundo De Pietro e Schneuwly (2014), o modelo didático tem tanto uma dimensăo prática (é uma ferramenta que impulsiona o agir didático) como uma força normativa - impossível de desconsiderar, pois se trata "do ensino, da maneira de guiar os alunos, da relaçấo mantida com a metodologia" (p. 69). É sempre o resultado de práticas linguageiras concedidas pela sociedade, portanto, sociohistóricas, o que faz com que seja um lugar de reflexôes sobre as práticas pedagógicas.

Para os pesquisadores genebrinos, o modelo pode ser explícito/conceitualizado, produzido conscientemente para um processo específico de transposiçâo didática, ou implícito/intuitivo, quando o docente já o tem internalizado pela sua própria prática docente. Neste artigo, tratamos do primeiro caso, aquele que deve ser pensado no interior de uma engenharia didática.

Quando conceitualizado, o modelo deve partir, primeiramente, de uma consulta aos especialistas do gênero (tanto estudiosos como usuários do gênero). Isso pode ser feito por meio de pesquisas, entrevistas, questionários, observaçăo direta ao contexto de produçấo e recepçâo do gênero. O segundo passo, de acordo com o método adotado pelo ISD, é a coleta de um corpus textual representativo do gênero para fins de descriçâo de suas características, para, assim, poder dimensionar as recorrências em relaçăo às capacidades de açâo, discursivas e linguístico-discursivas (SCHNEUWLY; DOLZ, 2004a) que o sujeito necessita mobilizar no ato da produçăo e leitura ${ }^{4}$ desse gênero.

Porém, a modelizaçăo didática necessita ainda de uma observaçâo das capacidades de linguagem dos alunos em relaçâo à produçâo/leitura do gênero - as que eles já possuem e quais devem ser desenvolvidas. Ou seja, é preciso adaptar o modelo teórico (BARROS 2012b) - primeira fase da modelizaçâo - ao contexto didático, a fim de se estabelecerem as dimensôes ensináveis do objeto de ensino para a intervençâo em curso.

Todavia o processo de modelizaçăo pode ser feito, a priori, sem levar em conta as capacidades de linguagem dos aprendizes, ou seja, o contexto de intervençăo - é o que Barros (2012b) tem chamado de modelo teórico:

[...] o modelo do gênero pode ser visto, a priori, apenas teoricamente, isto é, sua construçăo năo necessitaria levar em conta as capacidades dos alunos nem as particularidades do contexto de ensino. Ele pode ser elaborado, a princípio, de forma genérica e servir como base teórica para a elaboraçăo de diversas SD [sequências didáticas] - essas, sim, precisam ser adaptadas a um contexto de ensino específico, uma vez que se configuram ferramentas didáticas que possibilitam a transposiçăo do conhecimento teórico de um gênero para o conhecimento a ser ensinado (BARROS, 2012b, p. 15).

4 Embora a sequência didática tenha sido criada como um procedimento para o trabalho com a produçăo de textos, nâo é possível pensar que exista um trabalho de produçâo oral ou escrita sem a implicaçāo de atividades de leitura. 
Ou seja, é possível o pesquisador elaborar um modelo teórico de um gênero específico para, posteriormente, ser adaptado pelo professor como modelo didático para diversos contextos de ensino da língua; ou os dois processos da modelizaçăo - fase inicial da transposiçâo didática externa - podem ser pensados conjuntamente.

Cristovâo (2001, p. 43) aponta ainda outras funçôes para o modelo didático: "instrumento para a formaçăo de professores; ferramenta disponível para possibilitar adaptaçōes e mudanças nas sequências didáticas; indicaçōes de critérios de avaliaçâo do desenvolvimento das capacidades de linguagem que os alunos devem construir". Acreditamos, assim como a autora, que além de ser uma ferramenta indispensável na didatizaçăo de um objeto de ensino, a modelizaçăo pode ser também um instrumental valioso na formaçăo docente - seja inicial ou continuada. Isso porque, para se descrever um gênero (do ponto de vista contextual, discursivo e linguístico) e adaptá-lo a um contexto específico de ensino é necessário mobilizar uma gama de saberes (de diversos tipos e procedências) e articulá-los a um agir situado, desenvolvendo, com isso, capacidades docentes imprescindíveis para o ato de ensinar.

\section{SEQUÊNCIA DIDÁTICA DE GÊNEROS}

Dolz, Noverraz e Schneuwly (2004, p. 97) descrevem a sequência didática de gêneros (SDG) como "um conjunto de atividades escolares organizadas de maneira sistemática, em torno de um gênero textual oral ou escrito", o qual direciona a produçáo de diversas atividades didáticas. Conforme proposto pelos pesquisadores de Genebra, a SDG possui, basicamente, a seguinte estrutura:

- Apresentaçâo da situaçâo de comunicaçâo: momento em que o professor deve promover uma sensibilizaçấo em relaçăo ao gênero, de forma a criar/simular uma "necessidade" para a produçáo textual. Nessa fase, o professor apresenta o projeto de ensino à classe e o gênero no seu meio social.

- Primeira produçâo: avaliaçăo do nível de conhecimento do aluno sobre o gênero. Fase que "[...] terá papel de regulaçăo das atividades" (GONÇALVES; NASCIMENTO, 2010, p. 247), pois é por meio dela que o professor vê os erros dos alunos e seleciona as atividades que vâo ao encontro dessas dificuldades.

- Módulos: oficinas focadas em objetivos específicos para desenvolver atividades que trabalhem os "problemas" evidenciados pela primeira produçāo.

- Produçâo final: momento em que o aluno vai reescrever seu texto, a partir de processos de revisăo instaurados pelo professor. O aluno pode optar por desprezar a primeira produçăo e começar um texto novo, com base nos conhecimentos adquiridos nos módulos ou reescrever a sua primeira produçăo. Nesta fase, é possível ver se o aluno internalizou as operaçóes de linguagem do gênero, sistematizadas durante os módulos. É uma etapa que proporciona ao professor e aluno observarem o desenvolvimento da aprendizagem, por meio do confronto das produçōes inicial e final.

Como vemos, o foco de uma SDG é a produçăo textual. Evidentemente, para se escrever é preciso recorrer a leituras - para ter o que dizer, para ter modelos para a escrita - e a análises linguísticas - para se entender como a língua funciona no gênero alvo da produçấo. Entretanto, mesmo trabalhando a leitura e a análise da língua, a SDG 
privilegia o trabalho com a produçăo textual (oral ou escrita). É ela que direciona todas as atividades dos módulos.

Para ilustrarmos a funçâo das duas ferramentas didáticas (modelo didático e SDG) na perspectiva adotada pelo ISD, trazemos a Figura 1.

Figura 1- A transposição didática na perspectiva do ISD

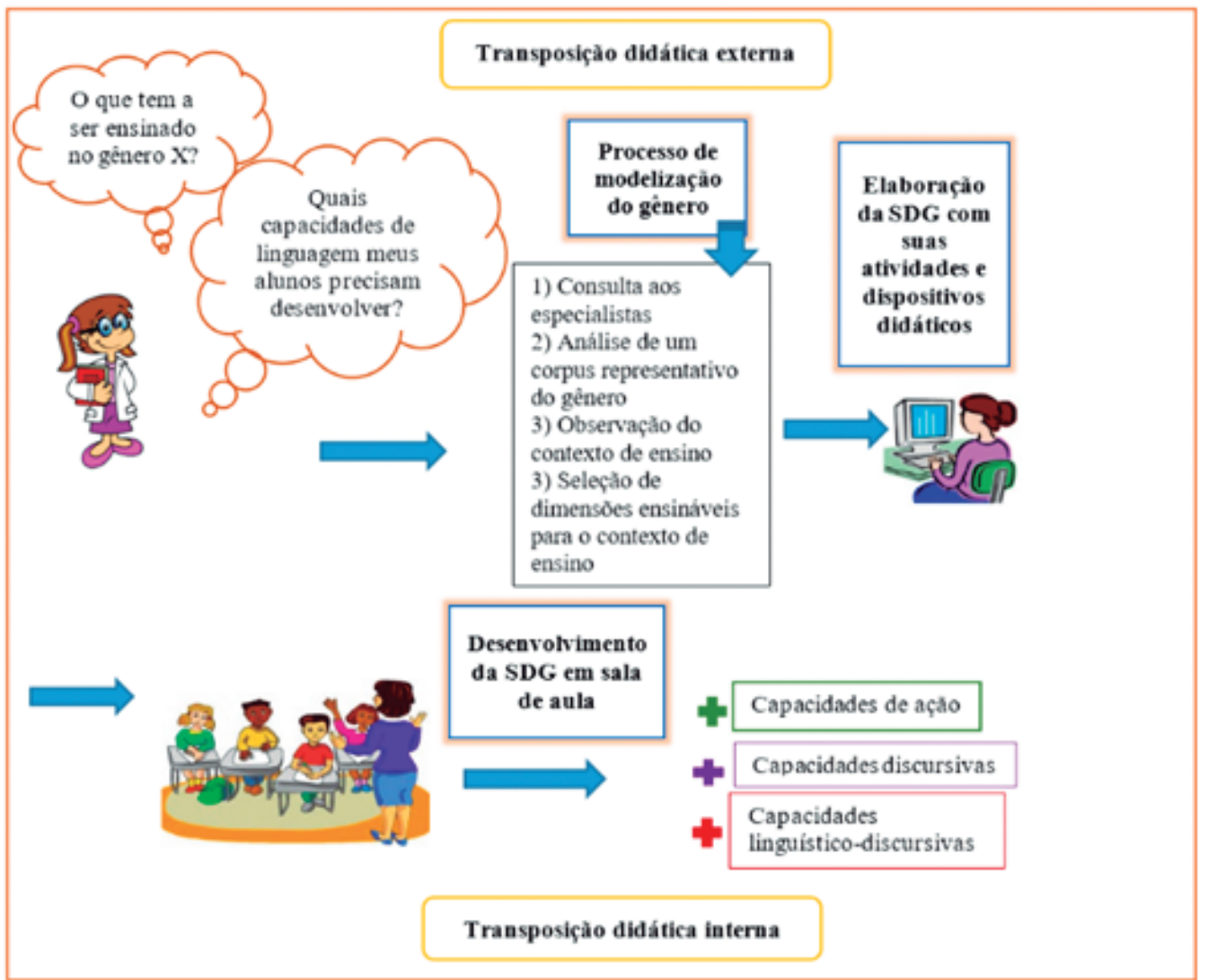

Fonte: As autoras

\section{O CONTEXTO DA INTERVENÇÃO DIDÁTICA: PIBID}

O modelo didático que apresentamos a seguir foi pensado para alunos do oitavo ano de uma escola pública de classe média participante do PIBID-Português (UENP), no ano de 2014. Neste projeto, de forma colaborativa, uma professora da Universidade (coordenadora do subprojeto PIBID), professoras do Ensino Fundamental (supervisoras do subprojeto PIBID) e alunos de Letras (alunos de iniciaçăo à docência) trabalharam para desenvolver novas capacidades intelectuais nos estudantes. $O$ foco do trabalho didático foi a produçăo de gêneros da esfera jornalística para a organizaçăo de um jornal escolar impresso - o Jornal PIBID, Primeira Ediçāo.

Um dos gêneros selecionados para compor o jornal escolar foi a carta do leitor (alvo desta pesquisa). Para que a carta se tornasse objeto a ser ensinado para os alunos do oitavo ano, foi necessário um trabalho de transposiçăo didática externa. Nesse processo, modelizamos o gênero (Cf.: tópico 4), tendo em vista a delimitaçăo de suas dimensōes 
ensináveis. Em seguida, construímos uma sinopse da sequência didática ${ }^{5}$ (provisória, pois foi sendo readaptada durante o processo de intervençáo) como ferramenta de planejamento e sistematizaçáo das açōes didáticas.

Na construçăo do modelo didático, percebemos que seria difícil trabalhar todas as possibilidades discursivas do gênero unificador da SDG, uma vez que cartas do leitor podem ser de reclamaçâo, solicitaçăo, agradecimento, denúncia, argumentativas, etc. Ou seja, năo daria para abordar todos os tipos de uma só vez, por se tratar de um projeto de ensino com foco na produçâo de vários gêneros textuais, os quais comporiam futuramente o jornal escolar. Sendo assim, nesse oitavo ano, optamos por produzir cartas do leitor que se aproximassem de uma modalidade bastante difundida nos jornais: a que traz uma argumentaçâo para defesa de um ponto de vista em relaçáo a uma questăo polêmica atual.

A temática proposta para a produçáo das cartas teve como foco duas questóes polêmicas: 1) A Copa do Mundo (2014) foi um evento relevante para o Brasil?; 2) Qual atitude o dono de um animal de estimaçáo deve tomar quando năo o quer mais? A primeira delas se justifica pela época em que foi desenvolvido o trabalho, junho de 2014; quanto à segunda proposta, o objetivo foi dialogar com a temática da reportagem que estava sendo escrita para compor o Jornal PIBID (gênero trabalhado por outro grupo PIBID, em outra turma), pois, nos jornais, muitas vezes, algumas cartas do leitor e reportagens dialogam sobre a mesma temática.

Um diferencial do nosso trabalho é que a produçăo da SDG se deu concomitantemente à intervençăo didática, ou seja, a cada aula novas atividades eram feitas, temáticas eram questionadas, textos escolhidos previamente perdiam lugar para outros (textos publicados recentemente que apresentavam mais potencial para aprendizagem), etc. Evidentemente, foi feita uma sinopse da SDG previamente (Cf.: tópico 4.2), na qual delineamos um planejamento geral com descriçâo dos objetos, conteúdos e atividades de cada módulo previsto. Porém, tal estratégia serviu apenas como um "projeto" para guiar as açôes, pois essas foram sempre sofrendo reconcepçōes (MACHADO; LOUSADA, 2010) no decorrer do processo. O formato desenvolvido possibilitou mais dinamicidade aos pibidianos e mais envolvimento dos alunos, pois as atividades foram se moldando às necessidades da intervençâo. Questôes como o tom adequado dos textos utilizados e os tipos de atividade e tarefa foram sempre pauta de reconcepçóes.

Um aspecto que desconsideramos na SDG foi a etapa de envio da carta ao editor. Como sabemos, as cartas do leitor de revistas e jornais, antes de serem publicadas em tais suportes, sâo enviadas ao editor, o qual pode realizar alteraçóes/adaptaçóes no texto. No nosso contexto de ensino, como tínhamos objetivos didáticos, entre eles o foco na autoria do aluno, optamos por nâo fazer uma editoraçăo; o texto que o aluno escreveu foi pautado no texto final que é publicado no jornal, com título, sem elementos epistolares clássicos como o cabeçalho com local e data, o vocativo e frases de despedida. Mesmo sem a editoraçáo clássica do jornal, as cartas dos alunos, foram se transformando durante a SDG, por causa das revisôes que aconteceram no processo.

5 A sinopse construída é uma ferramenta que explicita, módulo a módulo da SDG, os objetivos, objetos de ensino, atividades e dispositivos didáticos. 
Cabe esclarecer que no projeto PIBID náo temos a obrigaçăo de aferir notas ou conceitos aos alunos. Entretanto, entendemos que houve uma forma de avaliaçấo das produçóes, pois precisamos selecionar quais delas iriam ser publicadas no Jornal PIBID.

\section{PROCESSO DE MODELIZAÇÃO E DIDATIZAÇÃO DO GÊNERO "CARTA DO LEITOR"}

Para viabilizar a produçâo do jornal escolar cabe modelizar nâo só os gêneros selecionados como também o próprio jornal, uma vez que também precisamos didatizar o suporte textual. Esse trabalho de didatizaçăo do suporte proporcionou a resoluçâo de alguns questionamentos, entre eles: Como geralmente é estruturado o plano global de um jornal? Com qual objetivo ele é construído? Quais gêneros possuem mais valor social? Para tanto, primeiramente, elaboramos modelos teóricos (BARROS, 2012b) dos Cadernos da Folha de Londrina - jornal selecionado como modelo-base do projeto de pesquisa -, os quais propiciaram o conhecimento da esfera jornalística e de seus diversos gêneros textuais. Os resultados das pesquisas em questăo deram, assim, respaldo para a modelizaçâo didática (DE PIETRO; SCHNEUWLY, 2014) do jornal escolar, bem como para a delimitaçáo das potencialidades ensináveis dos gêneros selecionados para compor esse jornal.

\section{CARTA DO LEITOR: 0 QUE DIZEM OS ESPECIALISTAS DO GÊNERO}

Para Corrêa (2014, p. 148), o gênero carta do leitor "se apresenta em seçăo fixa, tendo como destinatário os produtores e leitores do jornal. As cartas tratam de uma variedade de assuntos e temas relacionados à mídia ou matérias, reportagens, artigos e/ou outros textos arrolados anteriormente ao periódico". A carta explora temas da mídia ou textos jornalísticos já publicados no jornal. A carta do leitor é, pois, um gênero epistolar que pressupóe a comunicaçâo entre indivíduos, pois nela há a comunicaçấo entre o produtor da carta e o editor da seçáo do jornal. Embora assinada pelo leitor, podemos falar, nesse caso, em coautoria, já que o editor tem liberdade para fazer adaptaçôes e cortes no texto - esse é um contrato explícito entre os interactantes. Sendo assim, a carta do leitor é "um diálogo entre leitores, apenas mediado pelo editor" (FRANCISCO, 2011, p. 131). Filho (2011, p. 137) adiciona que é "comum que haja [nas cartas do leitor] o acréscimo de um título temático (o qual é criado năo pelo leitor, mas pelo editor)". Portanto, a carta que é publicada é sempre o resultado do agir de dois atores: o leitor e o editor; o que se configura em um processo de coautoria (BEZERRA, 2010).

Filho (2011, p. 127) relata que, com o advento da internet, aumentou o envio de cartas do leitor aos jornais (via e-mail), por ser um processo mais fácil do que o tradicional, via correios. $O$ autor explica que tal situaçăo aumentou o fluxo de cartas que chegam ao editor, mas que o jornal năo ampliou o espaço destinado ao gênero: "enquanto a manifestaçấo de opiniăo do leitor tem crescido significativamente nos dias atuais, este crescimento náo se traduz no aumento das páginas de jornais destinados a este gênero" (FRANCISCO, 2011, p. 129).

Sobre os assuntos abordados pela carta, Melo $(1985)$ defende que esses se distanciam totalmente do momento de eclosâo do assunto, uma vez que ela pretende focar o outro lado do fluxo jornalístico: o do receptor, da coletividade. Nessa perspectiva, a 
carta é um "[...] espaço facultado aos cidadáos para que expresse seus pontos de vista, suas reivindicaçôes, sua emoçăo" (CARVALHO; GURCHEL, 2010, p. 3).

A carta é um espaço destinado ao leitor para expor sua opiniăo. “Nas cartas há a materializaçăo da intençáo discursiva dos seus autores e seu direito à palavra é garantido, pois săo detentores do saber, do poder e do saber fazer" (CHARAUDEAU, 1996 apud COSTA, 2005, p. 31). O leitor assume o papel de "comentarista, gerador de pautas e mesmo de redator de matérias" (FRANCISCO, 2011, p. 128), podendo ter inúmeros objetivos como: elogiar, reclamar, argumentar sobre algum tema, agradecer, informar, fazer uma propaganda, criticar, elogiar, etc. Esse fazer do leitor tem de ser respeitado, mesmo que a opiniâo defendida por ele nâo seja a da grande maioria, visto que ali é o espaço dele.

\section{A MODELIZAÇÃO DA CARTA DO LEITOR E SUA DIDATIZAÇÃO EM UMA SDG}

O modelo teórico do gênero "carta do leitor" foi feito com aporte da pesquisa bibliográfica (síntese no tópico anterior) e das cartas do leitor publicadas pela Folha de Londrina, uma vez que esse jornal tem grande repercussâo na regiâo atendida pelo subprojeto PIBID, ou seja, é um exemplar do letramento local (Cf.: NASCIMENTO, 2010; ROJO, 2009).

Já no processo de modelizaçâo didática levamos em consideraçăo as capacidades reais dos alunos, os objetivos de ensino e o contexto escolar, num processo de observaçâo da sala de aula, e de previsóes feitas sobre aquela determinada turma. Com base nessa observaçăo prévia, foi feito o processo de modelizaçâo do gênero, partindo do modelo teórico das cartas do leitor publicadas pela Folha de Londrina, o qual trazemos a seguir, com o objetivo de comparar com o modelo didatizado pelo projeto de ensino do PIBID. O modelo didático delimita as dimensôes ensináveis do gênero, partindo da sua pertinência para o contexto de intervençâo (subprojeto PIBID). Além disso, trazemos, paralelamente, as oficinas em que os objetos modelizados foram abordados.

\section{Quadro 2 - Síntese da modelização da carta do leitor: capacidades de ação}

\begin{tabular}{|c|c|c|}
\hline $\begin{array}{c}\text { Modelo teórico (Folha de Londrina) } \\
\text { Carta do Leitor }\end{array}$ & $\begin{array}{c}\text { Modelo didático (Jornal PIBID) } \\
\text { Carta do Leitor }\end{array}$ & $\begin{array}{c}\text { Didatização: } \\
\text { Oficina da SDG } \\
\text { (Cf.: Quadro 5) }\end{array}$ \\
\hline Esfera jornalística. & Esfera escolar, um simulacro da esfera & $\begin{array}{c}\text { OFICINAS } \\
\text { jornalística. }\end{array}$ \\
\hline $\begin{array}{c}\text { Agente produtor: leitor do jornal que assume } \\
\text { um papel de cidadão que deseja se expressar } \\
\text { publicamente em relação de um tema/fato } \\
\text { atual da região e de interesse comum. }\end{array}$ & $\begin{array}{c}\text { Agente produtor: aluno que assume o papel } \\
\text { de um leitor-cidadão que precisa expressar } \\
\text { seu ponto de vista em relação a questões } \\
\text { polêmicas (selecionadas em sala de aula) à }\end{array}$ & OFICINAS \\
$1,3,4$ \\
\hline $\begin{array}{c}\text { Receptor: assume o papel social de cidadão } \\
\text { crítico interessado em pontos de vista } \\
\text { diferentes em relação a questões atuais. }\end{array}$ & $\begin{array}{c}\text { Receptor: comunidade escolar que assume } \\
\text { o papel social de leitores de textos de alunos } \\
\text { (sentido de pertencimento). }\end{array}$ & OFICINAS \\
\hline $\begin{array}{c}\text { O objetivo é expressar uma visão em relação } \\
\text { a temas veiculados em mídias jornalísticas } \\
\text { (sobretudo no suporte onde a carta é }\end{array}$ & $\begin{array}{c}\text { O é objetivo expressar uma opinião em } \\
\text { relação a temas polêmicos propostos no } \\
\text { publicada) ou a fatos recentes da região. }\end{array}$ & $\begin{array}{c}\text { OFICINAS } \\
1,2,4\end{array}$ \\
\hline $\begin{array}{c}\text { Trata de temáticas e/ou fatos atuais que } \\
\text { podem escolar (para ser publicado no Jornal } \\
\text { leitor ou em outro texto da esfera jornalística. }\end{array}$ & $\begin{array}{c}\text { Trata de duas temáticas selecionadas pelo } \\
\text { subprojeto PIBID:1) Copa do Mundo de 2014 } \\
\text { e 2) Animais abandonados. }\end{array}$ & OFICINA \\
\hline
\end{tabular}




\section{Quadro 3 - Síntese da modelização da carta do leitor: capacidades discursivas}

\begin{tabular}{|c|c|c|}
\hline $\begin{array}{c}\text { Modelo teórico (Folha de Londrina) } \\
\text { Carta do Leitor }\end{array}$ & $\begin{array}{c}\text { Modelo didático (Jornal PIBID) } \\
\text { Carta do Leitor }\end{array}$ & $\begin{array}{c}\text { Didatização: } \\
\text { Oficina da SDG } \\
\text { (Cf.: Quadro 5) }\end{array}$ \\
\begin{tabular}{|c|c|c|} 
Plano textual global: título curto, geralmente, \\
com apenas um substantivo (pode ser criado \\
pelo editor do jornal); um único parágrafo; \\
texto assinado, com local e papel social do \\
leitor.
\end{tabular} & $\begin{array}{c}\text { Plano textual global: título curto, geralmente, } \\
\text { com apenas um substantivo (criado pelo } \\
\text { aluno); um parágrafo; traz imagem ilustrativa } \\
\text { da temática, assinatura, papel swocial } \\
\text { (aluno), série e escola. }\end{array}$ & $\begin{array}{c}\text { OFICINAS } \\
3,4\end{array}$ \\
\hline $\begin{array}{c}\text { Referência a alguma matéria jornalística } \\
\text { publicada anteriormente (para as cartas- } \\
\text { respostas - a grande maioria). }\end{array}$ & $\begin{array}{c}\text { Não foi modelizado, pois as cartas escritas } \\
\text { pelos alunos não seriam cartas-respostas. }\end{array}$ & XXX \\
\hline $\begin{array}{c}\text { Tipo de discurso mais comum: discurso } \\
\text { expositivo interativo. }\end{array}$ & $\begin{array}{c}\text { Discurso do EXPOR. Não foi modelizado se } \\
\text { o expor seria interativo ou teórico: decisão a } \\
\text { cargo do autor-aluno. }\end{array}$ & $\begin{array}{c}\text { OFICINA } \\
7\end{array}$ \\
\hline $\begin{array}{c}\text { Tipo de sequência predominante: sequência } \\
\text { explicativa e argumentativa. }\end{array}$ & $\begin{array}{c}\text { Tipo de sequência predominante: sequência } \\
\text { argumentativa (a partir de questões } \\
\text { polêmicas). }\end{array}$ & $\begin{array}{c}\text { OFICINAS } \\
7,8,9\end{array}$ \\
\hline
\end{tabular}

\section{Quadro 4 - Síntese da modelização da carta do leitor: capacidades linguístico-discursivas}

\begin{tabular}{|c|c|c|}
\hline $\begin{array}{l}\text { Modelo teórico (Folha de Londrina) } \\
\text { Carta do Leitor }\end{array}$ & $\begin{array}{l}\text { Modelo didático (Jornal PIBID) } \\
\text { Carta do Leitor }\end{array}$ & $\begin{array}{c}\text { Didatização: } \\
\text { Oficina da SDG } \\
\text { (Cf.: Quadro 5) }\end{array}$ \\
\hline $\begin{array}{l}\text { Pontuação: comum da linguagem lógico- } \\
\text { argumentativa, como dois pontos, travessão, } \\
\text { vírgula, ponto final. Pelo teor interativo do } \\
\text { texto, também podem ser encontrados pontos } \\
\text { de interrogação (com efeito de pergunta } \\
\text { retórica) e exclamação (para designar } \\
\text { entonação valorativa). }\end{array}$ & $\begin{array}{l}\text { Pontuação: comum da linguagem lógico- } \\
\text { argumentativa, como dois pontos, } \\
\text { travessão, vírgula, ponto final. Pelo teor } \\
\text { interativo do texto também podem ser } \\
\text { encontrados pontos de interrogação (com } \\
\text { efeito de pergunta retórica) e exclamação } \\
\text { (para designar entonação valorativa). }\end{array}$ & $\begin{array}{c}\text { OFICINAS } \\
\text { 9, 12, } 13 \\
\text { (Revisão/ } \\
\text { Reescrita/ } \\
\text { Retextualização) }\end{array}$ \\
\hline $\begin{array}{l}\text { Sinais gráficos: uso de aspas para marcar o } \\
\text { discurso indireto, uso de parênteses como } \\
\text { recurso explicativo ou exemplificativo ou como } \\
\text { forma de introduzir a voz do autor de forma } \\
\text { dialógica. }\end{array}$ & $\begin{array}{l}\text { Sinais gráficos: uso de aspas para marcar o } \\
\text { discurso indireto, uso de parênteses como } \\
\text { recurso explicativo ou exemplificativo ou } \\
\text { como forma de introduzir a voz do autor de } \\
\text { forma dialógica. }\end{array}$ & $\begin{array}{c}\text { OFICINAS } \\
\text { 9, 12, } 13 \\
\text { (Revisão/ } \\
\text { Reescrita/ } \\
\text { Retextualização) }\end{array}$ \\
\hline $\begin{array}{l}\text { Uso de conectivos lógicos (mas, portanto, } \\
\text { assim, dessa forma, etc.). }\end{array}$ & $\begin{array}{l}\text { Uso de conectivos lógicos (mas, portanto, } \\
\text { assim, dessa forma, etc.). }\end{array}$ & $\begin{array}{l}\text { OFICINA } \\
10\end{array}$ \\
\hline $\begin{array}{l}\text { Uso de modalizadores: lógicos, deônticos, } \\
\text { apreciativos e pragmáticos. }\end{array}$ & $\begin{array}{l}\text { Uso de modalizadores: lógicos, deônticos, } \\
\text { apreciativos e pragmáticos. }\end{array}$ & $\begin{array}{l}\text { OFICINA } \\
11\end{array}$ \\
\hline $\begin{array}{l}\text { Linguagem: formal, mas sem deixar de ter o } \\
\text { tom de "diálogo" com o leitor. }\end{array}$ & $\begin{array}{l}\text { Linguagem: formal, mas sem deixar de } \\
\text { ter o tom de "diálogo" com o leitor. O tom } \\
\text { formal na linguagem do aluno soa, muitas } \\
\text { vezes, como informal, por conta do seu } \\
\text { repertório lexical e sintático. }\end{array}$ & $\begin{array}{c}\text { OFICINAS } \\
\text { 9, 12, } 13 \\
\text { (Revisão/ } \\
\text { Reescrita/ } \\
\text { Retextualização) }\end{array}$ \\
\hline
\end{tabular}




\begin{tabular}{|c|c|c|}
\hline $\begin{array}{c}\text { Uso frequente do pronome "você" para referir- } \\
\text { se ao leitor. Uso frequente de construções } \\
\text { prescritivas (modo imperativo, modalizadores } \\
\text { da ordem do dever, precisar) para aconselhar, } \\
\text { dar sugestões, ordens, ou seja, incitar o leitor a } \\
\text { fazer alguma ação. }\end{array}$ & $\begin{array}{c}\text { A referência ao leitor (no diálogo ou na } \\
\text { incitação de ações) fica a cargo do autor- } \\
\text { aluno (não aparece explicitamente no } \\
\text { modelo). }\end{array}$ & $\begin{array}{c}\text { OFICINAS } \\
\text { 9, 12, } 13 \\
\text { (Revisão/ } \\
\text { Reescrita/ } \\
\text { Retextualização) }\end{array}$ \\
\hline $\begin{array}{l}\text { Pessoa do discurso assumida pelo autor: } \\
\text { comum uso da primeira pessoa do singular (às } \\
\text { vezes, ela aparece implícita, quando o autor } \\
\text { usa, por exemplo, o imperativo para incitar uma } \\
\text { ação no leitor - se tem um TU, tem também } \\
\text { um eu); é comum o autor assumir um Nós para } \\
\text { se colocar na condição de um grupo (povo, } \\
\text { eleitores, grupos de professores, etc.); também } \\
\text { aparecem discursos }\end{array}$ & $\begin{array}{l}\text { A posição enunciativa não foi modelizada } \\
\text { didaticamente: decisão a cargo do aluno- } \\
\text { autor. }\end{array}$ & $\begin{array}{c}\text { OFICINAS } \\
\text { 9, 12, } 13 \\
\text { (Revisão/ } \\
\text { Reescrita/ } \\
\text { Retextualização) }\end{array}$ \\
\hline $\begin{array}{l}\text { Tempo de ancoragem: presente (momento da } \\
\text { ação de escrever a carta) }\end{array}$ & $\begin{array}{l}\text { Tempo de ancoragem: presente (momento } \\
\text { da ação de escrever a carta) }\end{array}$ & $\begin{array}{c}\text { OFICINAS } \\
\text { 9, 12, } 13 \\
\text { (Revisão/ } \\
\text { Reescrita/ } \\
\text { Retextualização) }\end{array}$ \\
\hline $\begin{array}{l}\text { Vozes enunciativas: vozes sociais diversas } \\
\text { (implícitas ou explícitas); vozes de personagens } \\
\text { (citações), voz do autor. }\end{array}$ & $\begin{array}{l}\text { Vozes enunciativas: vozes sociais diversas } \\
\text { (implícitas ou explícitas); voz do autor (caso } \\
\text { o aluno assuma a primeira pessoa). }\end{array}$ & $\begin{array}{c}\text { OFICINAS } \\
\text { 9, 12, } 13 \\
\text { (Revisão/ } \\
\text { Reescrita/ } \\
\text { Retextualização) }\end{array}$ \\
\hline
\end{tabular}

Na concepçăo da metodologia das SDG é preciso saber adaptar o gênero de referência social à situaçăo didática proposta. Por isso, o professor deve ter sempre em mente o modelo didático (SCHNEUWLY; DOLZ, 2004a) do gênero para poder mediar o processo de ensino, fazendo avaliaçóes e intervençóes coerentes e que levem o aluno a compreender o objeto da escrita, se construindo como ator do seu agir linguageiro.

A modelizaçâo teórica, como é possível observar pelos quadros, direciona a delimitaçāo das dimensōes ensináveis do gênero para o contexto de intervençāo didática. No caso da carta do leitor, as adaptaçōes do modelo teórico para o didático se dâo de forma mais significativa no plano contextual, isso porque o gênero, embora permaneça um instrumento de interaçâo (nesse caso, aluno-comunidade escolar), é agora, principalmente, um gênero a aprender (SCHNEUWLY; DOLZ, 2004b, p. 81). Seu contexto de produçáo năo é mais o mesmo, uma vez que agora ele sofre as coerçóes naturais do processo didático: é produzido por outra instituiçâo social, por outros atores, com propósitos comunicativos que incorporam ao seu estatuto social interesses voltados para o ensino. Veja, por exemplo, que o objetivo da escrita da carta no ambiente didático, embora mantenha os traços sociais do objeto de referência, muda significativamente, pois uma coisa é se sentir "tocado" por uma questăo a ponto de publicar uma carta em um jornal comercial de considerável abrangência, expondo e defendendo seu ponto de vista; outra coisa é, a partir de uma questáo polêmica proposta em sala de aula, tomar um posicionamento e selecionar argumentos (muitas vezes năo acessíveis aos alunos) para defendê-lo. A seleçâo prévia das temáticas foi uma decisăo tomada para sistematizar melhor as atividades propostas para a SDG, uma vez que, assim, elas poderiam ser planificadas com antecedência, o que năo ocorreria se elas "nascessem" de discussôes em sala de aula. Evidentemente, tal decisăo tira, em parte, a autonomia e o grau de 
autoria do aluno. Por outro lado, ganha-se em produtividade e planejamento didático. Sâo caminhos que a modelizaçáo didática impóe no seu percurso como ferramenta mediadora do ensino.

No plano discursivo, é possível também perceber as influências do novo contexto de interaçáo. Como objeto de referência social, a carta do leitor náo costuma trazer imagens ilustrativas, porém, para o contexto de intervençăo, cujo alvo seria a publicaçăo de um jornal escolar, esse recurso é elencado como essencial para dar dinamicidade às produçooes, servindo de "chamariz" para a leitura dos textos como podemos conferir no Anexo A.

Também é destaque no nível discursivo a seleçâo prévia do tipo de carta que seria escrito, já que o gênero epistolar em questăo é bastante heterogêneo discursivamente, como vimos na seçáo 4.1. Na didatizaçâo, é delimitada uma modalidade, a carta do leitor argumentativa (mas que nâo responde explicitamente a uma matéria jornalística anterior). Tal escolha, ao mesmo tempo em que reduz as possibilidades discursivas, imprime mais sistematizaçăo ao processo de ensino, uma vez que se consegue centrar em um modelo textual de referência mais estável, fato que favorece o processo natural de imitaçâo, processo esse que a aprendizagem nâo tem como ignorar (Cf.: VIGOTSKI, 2008).

Por outro lado, é dada mais flexibilidade à forma de enunciaçăo. O modelo didático náo delimita se o expor será interativo (deixando marcas do contexto de produçáo, sobretudo, expondo o eu que se coloca no texto), teórico (mantendo um distanciamento do contexto, produzindo, com isso, mais objetividade discursiva) ou misto teórico-interativo (Cf.: os conceitos mencionados em BRONCKART, 2003, p. 165-209). Diferentemente da questăo anterior, nesse caso, o objetivo foi buscar caminhos para um discurso mais autoral. O modelo didático tenta, dessa forma, balancear os dois polos: o gênero como objeto social e o gênero como objeto didático.

No nível linguístico-discursivo, sâo poucas as reconcepçōes feitas no modelo teórico. A mais expressiva diz respeito ao fato de se deixar a cargo do aluno-autor a decisâo de se colocar como primeira pessoa do singular, do plural ou manter-se distante, argumentando como uma entidade abstrata (embora todas as cartas sejam assinadas). Da mesma forma, o modelo náo engessa a forma como o aluno-autor deve dialogar com o leitor do jornal, pois é comum nas cartas do leitor publicadas no suporte investigado uma referência explícita à segunda pessoa (VOCÊ) da interaçăo, por meio de invocaçăo direta ou pelo uso de estratégias injuntivas que incitam o leitor a agir (passagens de sugestōes, ordens, alerta, etc.). Esse é um fato interessante, visto que, mesmo nâo modalizada didaticamente e, portanto, náo sendo fruto de um trabalho sistemático, tal dimensâo foi encontrada em várias cartas dos alunos, talvez por imitaçâo dos exemplares lidos em sala. Veja, por exemplo, como o aluno termina sua carta sobre o abandono de câes, invocando seu leitor a pensar sobre um possível ato de abandono: “Pense [você] antes de querer abandonar um animal, porque há muitas pessoas que querem adotar um!" (Carta publicada no Jornal PIBID, Primeira Ediçăo, com o título "Căes maltratados sem pudor"). O fato exposto mostra, como vemos, o aluno se transformando em ator do seu dizer.

Outro ponto a se destacar na modelizaçâo didática é a seleçâo dos modalizadores como uma dimensăo ensinável do gênero. Na tradiçấo escolar, os modalizadores, dificilmente, săo elencados como objetos de ensino. Entretanto, seu potencial como 
elemento desencadeador de sentidos no texto é muito grande, uma vez que a modalizaçâo revela as avaliaçōes do agente-produtor ou dos personagens e instituiçóes sociais mobilizadas no discurso frente ao conteúdo temático que está em jogo. No caso da carta do leitor, um gênero argumentativo da esfera pública, mostrar para o aluno as possibilidades desses elementos linguístico-discursivos na construçăo de sentidos dos textos é fundamental para que ele possa tanto fazer uma leitura mais crítica das cartas que circulam nas mídias como produzir textos de forma mais consciente, sabendo o valor e a significaçáo que as palavras e expressóes modalizadoras carregam em si.

O modelo didático apresentado procura, pois, seguir os critérios de validade (Cf.: DOLZ; GAGNON; DECÂNDIO, 2010, p. 48-49): legitimidade (ancorado no modelo teórico), pertinência (adequaçâo ao contexto de intervençâo do PIBID) e solidarizaçăo (equilíbrio entre os dois critérios). Ele é o eixo condutor da elaboraçăo da sinopse final da SDG (QUADRO 5), a qual foi sendo construída no decorrer da intervençâo, processo que possibilitou maior flexibilizaçāo das açōes didáticas.

Para o projeto PIBID, o modelo teórico/didático foi a ferramenta que orientou a construçăo da SDG. Serviu para selecionar as dimensóes ensináveis e planificar as atividades que se pretendiam desenvolver. No nosso caso, como dissemos, a SDG foi se construindo de acordo com a intervençăo didática, tendo como ferramenta de planejamento uma sinopse contendo: os títulos de cada módulo/oficina, juntamente com os objetivos, os objetos (conteúdos) e as atividades elaboradas; sinopse essa que apresentamos a seguir para que possamos, em seguida, analisá-la à luz da modelizaçáo do gênero.

Quadro 5 - Sinopse da sequência didática do gênero "carta do leitor"

\begin{tabular}{|c|c|c|c|}
\hline OFICINAS & OBJETIVOS & OBJETOS & ATIVIDADES \\
\hline $\begin{array}{l}\text { OFICINA 1: } \\
\text { Contextualizando o } \\
\text { projeto de ensino }\end{array}$ & $\begin{array}{l}\text { Apresentar o projeto } \\
\text { do jornal escolar. } \\
\text { Contextualizar a } \\
\text { produção jornalística, } \\
\text { com foco nos } \\
\text { gêneros opinativos do } \\
\text { jornal. }\end{array}$ & $\begin{array}{l}\text { Projeto do jornal } \\
\text { escolar. } \\
\text { Contexto de produção } \\
\text { de gêneros do jornal: } \\
\text { foco no suporte. }\end{array}$ & $\begin{array}{l}\text { Apresentação do projeto de ensino } \\
\text { discursivamente. } \\
\text { Discussão oral do contexto de produção } \\
\text { do jornal, por meio de exemplares do } \\
\text { jornal Folha de Londrina. } \\
\text { Apresentação da seção "opinião" do } \\
\text { jornal e dos gêneros que a compõem. }\end{array}$ \\
\hline $\begin{array}{c}\text { OFICINA 2: } \\
\text { Opinando para } \\
\text { se colocar como } \\
\text { cidadão no mundo }\end{array}$ & $\begin{array}{l}\text { Tomar consciência da } \\
\text { argumentação no ato } \\
\text { de opinar. } \\
\text { Compreender o } \\
\text { que é uma questão } \\
\text { polêmica. }\end{array}$ & $\begin{array}{l}\text { O ato de opinar e } \\
\text { argumentar. } \\
\text { Questões polêmicas. }\end{array}$ & $\begin{array}{l}\text { 1. Visualização do vídeo lúdico "O Fim do } \\
\text { Recreio". } \\
\text { 2. Questionário oral sobre o vídeo. } \\
\text { 3. Resposta escrita à pergunta: Qual a } \\
\text { ideia defendida pelo deputado no vídeo? } \\
\text { Você concorda? Por quê? } \\
\text { 4. Competição oral: foco na } \\
\text { argumentação a partir de questões } \\
\text { polêmicas apresentadas pelo professor. }\end{array}$ \\
\hline $\begin{array}{l}\text { OFICINA 3: } \\
\text { Comparando os } \\
\text { tipos de cartas }\end{array}$ & $\begin{array}{c}\text { Identificar as } \\
\text { diferentes } \\
\text { modalidades de carta } \\
\text { e compreender o } \\
\text { funcionamento de } \\
\text { cada um. }\end{array}$ & $\begin{array}{c}\text { Modalidades diferentes } \\
\text { de carta. }\end{array}$ & $\begin{array}{l}\text { 1. Atividade escrita de comparação entre } \\
\text { a carta pessoal, carta do leitor e carta } \\
\text { ao leitor, a partir de um questionário com } \\
\text { questões abertas e fechadas. }\end{array}$ \\
\hline
\end{tabular}




\begin{tabular}{|c|c|c|c|}
\hline $\begin{array}{l}\text { OFICINA 4: } \\
\text { Lendo cartas do } \\
\text { leitor }\end{array}$ & $\begin{array}{c}\text { Compreender } \\
\text { sucintamente o } \\
\text { contexto de produção } \\
\text { e o plano textual } \\
\text { global da carta do } \\
\text { leitor argumentativa. }\end{array}$ & $\begin{array}{l}\text { Contexto de produção } \\
\text { e plano textual global } \\
\text { da carta do leitor } \\
\text { argumentativa. }\end{array}$ & $\begin{array}{l}\text { 1. Presentificação do gênero "carta do } \\
\text { leitor" no suporte impresso: leitura e } \\
\text { análise de cartas de leitor argumentativas. }\end{array}$ \\
\hline $\begin{array}{l}\text { OFICINA 5: } \\
\text { Aprofundando no } \\
\text { tema para poder se } \\
\text { posicionar }\end{array}$ & $\begin{array}{l}\text { Conhecer melhor } \\
\text { sobre os temas das } \\
\text { cartas que serão } \\
\text { produzidas. }\end{array}$ & $\begin{array}{l}\text { Conteúdo temático } \\
\text { das produções das } \\
\text { cartas do leitor dos } \\
\text { alunos. }\end{array}$ & $\begin{array}{l}\text { 1. Discussão oral sobre os temas } \\
\text { "Copa do Mundo 2014" e "animais } \\
\text { abandonados", a partir da leitura e escuta } \\
\text { de textos e vídeos diversos. } \\
\text { 2. Síntese escrita de um dos textos } \\
\text { discutidos (em grupos). }\end{array}$ \\
\hline $\begin{array}{c}\text { OFICINA 6: } \\
\text { Escrevendo a } \\
\text { primeira produção }\end{array}$ & $\begin{array}{l}\text { Produzir a primeira } \\
\text { versão da carta do } \\
\text { leitor para diagnóstico } \\
\text { das capacidades de } \\
\text { linguagem. }\end{array}$ & $\begin{array}{l}\text { Primeira produção do } \\
\text { gênero carta do leitor. }\end{array}$ & $\begin{array}{l}\text { 1. Produção de uma carta do leitor } \\
\text { individual sobre um dos dois temas } \\
\text { propostos. }\end{array}$ \\
\hline $\begin{array}{c}\text { OFICINA 7: } \\
\text { Comparando } \\
\text { diferentes cartas do } \\
\text { leitor }\end{array}$ & $\begin{array}{c}\text { Entender } \\
\text { semelhanças e } \\
\text { diferenças entre } \\
\text { alguns modelos } \\
\text { discursivos de carta } \\
\text { do leitor. }\end{array}$ & $\begin{array}{l}\text { Distinção de diferentes } \\
\text { modelos discursivos } \\
\text { de carta do leitor. }\end{array}$ & $\begin{array}{l}\text { 1. Atividade escrita de comparação } \\
\text { de diferentes modelos discursivos de } \\
\text { cartas do leitor: denúncia, comentário, } \\
\text { agradecimento, etc. (questionários com } \\
\text { perguntas abertas e fechadas). } \\
\text { 2. Atividade de leitura para identificação } \\
\text { da função e do projeto de dizer de } \\
\text { diferentes cartas do leitor (em jornais). } \\
\text { 3. Atividade oral sobre o teor } \\
\text { argumentativo de cada carta. }\end{array}$ \\
\hline $\begin{array}{c}\text { OFICINA 8: } \\
\text { Analisando a } \\
\text { argumentação em } \\
\text { artigo de opinião }\end{array}$ & $\begin{array}{c}\text { Entender o que } \\
\text { são argumentos e } \\
\text { o funcionamento } \\
\text { da sequência } \\
\text { argumentativa. } \\
\text { Compreender o peso } \\
\text { de cada argumento } \\
\text { no projeto de dizer do } \\
\text { texto. }\end{array}$ & $\begin{array}{l}\text { Argumentos } \\
\text { e sequência } \\
\text { argumentativa. }\end{array}$ & $\begin{array}{l}\text { 1. Leitura e discussão oral do artigo } \\
\text { de opinião "Truculência na internet" de } \\
\text { Marcelo Leite. } \\
\text { 2. Atividade escrita de análise } \\
\text { do funcionamento da sequência } \\
\text { argumentativa no artigo de opinião. } \\
\text { 3. Atividade oral: apontamento dos } \\
\text { argumentos utilizados pelo autor; análise } \\
\text { dos argumentos mais fortes. }\end{array}$ \\
\hline $\begin{array}{l}\text { OFICINA 9: } \\
\text { Retextualizando a } \\
\text { argumentação }\end{array}$ & $\begin{array}{l}\text { Identificar o } \\
\text { posicionamento } \\
\text { e os principais } \\
\text { argumentos de um } \\
\text { artigo de opinião para } \\
\text { retextualizá-lo em } \\
\text { uma carta do leitor } \\
\text { argumentativa. }\end{array}$ & $\begin{array}{l}\text { Retextualização } \\
\text { entre gêneros do } \\
\text { argumentar. }\end{array}$ & $\begin{array}{l}\text { 1. Produção de uma carta do leitor } \\
\text { a partir de um artigo de opinião: } \\
\text { retextualização. }\end{array}$ \\
\hline $\begin{array}{l}\text { OFICINA 10: } \\
\text { Articulando as } \\
\text { ideias por meio de } \\
\text { conectivos }\end{array}$ & $\begin{array}{l}\text { Entender o que são } \\
\text { conectivos textuais } \\
\text { e seu funcionamento } \\
\text { discursivo nos textos } \\
\text { argumentativos, } \\
\text { sobretudo, na carta } \\
\text { do leitor. } \\
\text { Saber usar } \\
\text { os conetivos } \\
\text { lógicos em textos } \\
\text { argumentativos. }\end{array}$ & $\begin{array}{l}\text { Conectivos textuais } \\
\text { na carta do leitor } \\
\text { argumentativa. }\end{array}$ & $\begin{array}{l}\text { 1. Leitura e discussão do texto "Fumante } \\
\text { não é excluído. É vítima" (Jussara } \\
\text { Fiterman). } \\
\text { 2. Atividade oral de identificação e } \\
\text { compreensão do funcionamento de } \\
\text { conectivos que atuam como oposição de } \\
\text { ideias, adição de ideias. } \\
\text { 3. Atividade escrita com perguntas } \\
\text { abertas e fechadas sobre o uso de } \\
\text { conectivos no texto analisado. } \\
\text { 4. Discussão e correção oral da atividade. }\end{array}$ \\
\hline
\end{tabular}




\begin{tabular}{|c|c|c|c|}
\hline $\begin{array}{l}\text { OFICINA 11: } \\
\text { Modalizando }\end{array}$ & $\begin{array}{c}\text { Entender o } \\
\text { funcionamento de } \\
\text { certos modalizadores } \\
\text { textuais e sua } \\
\text { importância } \\
\text { enunciativa na } \\
\text { argumentação. } \\
\text { Saber mobilizar } \\
\text { coerentemente } \\
\text { modalizadores } \\
\text { textuais num projeto } \\
\text { de dizer. }\end{array}$ & $\begin{array}{l}\text { Modalizadores } \\
\text { textuais. }\end{array}$ & $\begin{array}{l}\text { 1. Leitura e discussão do texto } \\
\text { "Brutalidade não pode ser reação à } \\
\text { cantada" (Jairo Bouer). } \\
\text { 2. Atividade escrita de identificação, } \\
\text { reflexão e uso de modalizadores textuais. } \\
\text { 3. Discussão e correção oral da atividade. } \\
\text { 4. Atividade escrita, com perguntas } \\
\text { abertas e fechadas, em relação ao uso de } \\
\text { modalizadores. }\end{array}$ \\
\hline $\begin{array}{l}\text { OFICINA 12: } \\
\text { Exercitando a revisão } \\
\text { e reescrita textual }\end{array}$ & $\begin{array}{l}\text { Tomar consciência } \\
\text { em relação a vários } \\
\text { problemas da escrita } \\
\text { (problemas de } \\
\text { ordem transversal } \\
\text { ou próprios da } \\
\text { discursividade } \\
\text { da carta do leitor } \\
\text { argumentativa). }\end{array}$ & $\begin{array}{l}\text { Revisão e reescrita } \\
\text { do gênero "carta do } \\
\text { leitor". }\end{array}$ & $\begin{array}{c}\text { 1. Revisão coletiva da carta do leitor, a } \\
\text { partir de cartas do leitor dos alunos ou } \\
\text { fragmentos do texto (em slides). } \\
\text { 2. Atividade de reescrita individual de } \\
\text { uma carta do leitor de um dos alunos, } \\
\text { a partir de uma lista de constatações } \\
\text { das características (de ação, discursiva, } \\
\text { linguístico-discursiva) da carta do leitor } \\
\text { argumentativa. }\end{array}$ \\
\hline $\begin{array}{c}\text { OFICINA 13: } \\
\text { Produzindo a } \\
\text { versão final da carta } \\
\text { do leitor para ser } \\
\text { publicada no Jornal } \\
\text { PIBID }\end{array}$ & $\begin{array}{l}\text { Consolidar o } \\
\text { aprendizado sobre a } \\
\text { escrita da carta do } \\
\text { leitor argumentativa. }\end{array}$ & $\begin{array}{l}\text { Reescrita do gênero } \\
\text { carta do leitor } \\
\text { argumentativa. }\end{array}$ & $\begin{array}{l}\text { 1. Reescrita da primeira produção da } \\
\text { carta do leitor, a partir de correção prévia } \\
\text { do professor (primeira revisão) e lista de } \\
\text { constatação do gênero. }\end{array}$ \\
\hline
\end{tabular}

A sinopse da SDG apresentada é a última versăo do processo de didatizaçăo. Sumariza e explicita os objetivos, objetos e atividades desenvolvidas para o projeto de ensino da carta do leitor, organizando-os em oficinas, cada qual com o foco diferenciado. Ela mobiliza, com estratégias diversas, os objetos selecionados como ensináveis na modelizaçăo didática do gênero - parâmetro inicial para a construçăo da SDG - e outros que foram sendo percebidos durante a intervençăo didática. Nesse sentido, cabe aqui analisar: a articulaçâo entre o modelo didático e a didatizaçâo dos objetos de ensino; as reconcepçôes necessárias na transposiçâo didática interna; o peso das capacidades de linguagem no trabalho final; as estratégias de didatizaçâo dos objetos a ensinar; para assim conseguirmos discutir o papel da modelizaçăo e do planejamento no processo de ensino.

Para iniciar a análise, destacamos um fato bastante próprio das SDG elaboradas por pesquisadores/professores brasileiros: um aprofundamento da etapa que o ISD denomina de apresentaçăo da situaçâo. Na SDG analisada, essa etapa comporta as oficinas 1, 2, 3, 4 e 5 . O que deveria ser apenas uma apresentaçăo do gênero e do projeto acaba se estendendo para um trabalho sistemático com foco no contexto de produçáo e no plano textual global do gênero, ato de opinar e argumentar, questóes polêmicas, modalidades diferentes de carta, conteúdo temático das produçóes. Mesmo que a metodologia das SDG proponha que a sistematizaçăo dos objetos de ensino aconteça, efetivamente, após a primeira produçăo diagnóstica, alguns pesquisadores têm detectado a importância de uma presentificaçâo (Cf.: AEBY-DAGHÉ; DOLZ, 2008) mais efetiva do gênero para que o aluno possa realizar a versâo inicial do seu texto (Cf.: BARROS, 
2015). Costa-Hübes e Simioni (2014) apresentam, inclusive, um esquema ampliado da SDG, trazendo um módulo de reconhecimento do gênero, anterior à fase da primeira produçăo.

No caso da SDG analisada, é possível verificar que mesmo a ampliaçâo do repertório temático foi didatizada na fase da apresentaçăo da situaçăo. Nâo vemos problema nessa opçấo, mas entendemos que, nesse caso, a discussâo sobre a temática deve ser reiterada depois, quando os alunos estiverem em processo de reescrita textual. Isso porque a carência de repertório de conteúdo empobrece muito a escrita do estudante, sobretudo, num gênero argumentativo em que o que se tem a dizer é fundamental para a construçấo do projeto de dizer. Compreendemos que o aluno deve, sempre que o projeto de ensino possibilitar, escolher a temática da carta que irá escrever. No projeto em questăo a pré-seleçâo ocorreu por causa da necessidade de se planejar atividades previamente, uma vez que esse se insere em um programa de formaçăo inicial de professores centrado na instrumentalizaçăo formativa para a produçăo de materiais didáticos, o que força, de certa maneira, a uma planificaçăo, mesmo que provisória, das atividades didáticas. Todavia, hoje temos consciência de que isso pode ser desmotivador para o aluno, pois seria bem mais significativo que a questăo polêmica partisse da sua vivência como cidadăo e náo fosse imposta pelo projeto didático.

No que se refere aos objetos "contexto de produçăo", implicados nas capacidades de açáo do ato linguageiro, como vemos no Quadro 2, eles foram sistematizados nas oficinas 1, 2, 3 e 4. A oficina 1 busca presentificar o suporte e a seçâo do jornal que trabalha com a opiniăo; a 2, ao trabalhar o ato de opinar, envolve o aluno nos propósitos comunicativos do gênero; a 3 traz um confronto entre diferentes modalidades de cartas, o que, com certeza, faz com que o aluno tenha mais clareza do contexto de produçấo da carta do leitor e sua relaçấo direta com a textualidade (ou seja, a textualidade é confrontada com suas condiçóes externas de produçâo); e, por fim, a oficina 4 os elementos que parametrizam o contexto săo vistos na sua relaçáo com o plano textual global do gênero. Por essa análise, é possível verificar que a concepçăo de língua adotada pelo projeto parte da ideia que ela é sempre resultado de uma interaçâo, o que pressupóe sempre a compreensăo das condiçóes sociodiscursivas de produçăo e recepçâo dos textos que materializam as práticas de linguagem. É preciso ressaltar que mesmo o contexto de produçấo sendo atrelado sistematicamente a certas oficinas, seus elementos foram mobilizados e retomados durante toda a SDG. Isso porque a textualidade só tem significado numa perspectiva interacional se articulada às coerçóes exercidas pela situacionalidade sociodiscursiva.

No caso das capacidades discursivas, a análise mostra uma ênfase na sequência argumentativa, já que a modalidade da carta do leitor contempla a discursividade do argumentar. A argumentaçăo, sua planificaçăo sequencial e suas estratégias foram alvo de três oficinas - 7, 8 e 9. A oficina 7 năo é voltada especificamente para esse fim, mas, ao colocar em evidência diferentes modalidades de carta do leitor, a argumentaçấo acaba aparecendo como uma característica que diferencia e aproxima a discursividade de cada uma. Aliás, a comparaçâo é uma estratégia que permite que o aluno visualize as características de um objeto e entenda o seu funcionamento, a partir do confronto com pares semelhantes ou divergentes. As oficinas 8 e 9 abordam a argumentaçăo a partir do gênero "artigo de opiniăo". Embora a SDG tenha como eixo a carta do leitor, é possível tomar outros gêneros como ferramentas para a sistematizaçăo de objetos a 
serem didatizados, no caso em pauta, o artigo de opiniâo é que faz a mediaçăo do ensino da argumentaçăo. A escolha do gênero foi pautada no seu aprofundamento argumentativo, característica que a carta do leitor perde, muitas vezes, durante o seu processo de publicaçăo (cortes e adaptaçóes do editor). O importante é o aluno ter consciência do objeto que se coloca em foco em cada oficina e sua relaçăo com o projeto de ensino da escrita. Para isso, é importante que o professor mobilize a todo o momento gestos didáticos que acionem a memória das aprendizagens para "costurar" as diversas oficinas da SDG (Cf.: BARROS, 2013).

Ainda em relaçăo aos aspectos discursivos, vemos que o objeto modelizado "plano textual global" foi sistematizado na fase da apresentaçăo da situaçăo, nas oficinas 3 e 4. Importante destacar que esse objeto se refere ao planejamento e organizaçăo mais geral do texto (Cf.: DOLZ, GAGNON, DECÂNDIO, 2010) e por isso precisa, necessariamente, ser trabalhado no início do projeto para que o aluno possa, depois, associá-lo com outros aspectos da discursividade e textualidade do gênero. Já o discurso do EXPOR, que, como vimos, apenas foi modalizado didaticamente de forma mais geral, em oposiçăo ao discurso do NARRAR e sem entrar na diferenciaçăo entre expor teórico e interativo, năo recebeu nenhuma oficina específica, visto que seu conceito é muito complexo para ser sistematizado para o nível de ensino em foco. É fácil o aluno diferenciar um texto narrativo de expositivo, mas năo é fácil, nem para o professor, entender o que os caracteriza e os diferencia. Dessa forma, por se tratarem de alunos de oitavo ano, a opçāo foi apenas por trabalhar superficialmente essa característica na oficina voltada para a comparaçấo de diferentes cartas do leitor.

Em relaçâo às dimensôes relacionadas à capacidade linguístico-discursiva, a análise mostra (Quadro 4) que muitos objetos que foram modalizados didaticamente năo săo alvo de ensino deliberado em uma oficina específica, ficando a sua abordagem por conta das intervençōes realizadas no processo de revisăo/reescrita textual. Isso é muito comum nos projetos de escrita mediados pela metodologia das SDG, uma vez que se parte do texto do próprio aluno para explicitar problemas linguístico-discursivos de diversas ordens, como é o caso da pontuaçăo, do uso de sinais notacionais (aspas, travessâo, etc.), do funcionamento da temporalidade, etc.

Um dos processos fundamentais do ensino da escrita consiste em reler e revisar o texto de maneira crítica, e reescrevê-lo. Modificar a organizaçáo do texto a partir de um novo planejamento, introduzir um novo parágrafo, expandir ou desenvolver um argumento, reformular uma frase, identificar um erro gramatical, lexical ou ortográfico para melhorar a primeira versáo do texto pode ser uma forma de ensino. [...] Os alunos têm muitas dificuldades em rever e melhorar os seus próprios textos sem a ajuda do professor. Uma das principais inovaçóes metodológicas no ensino da escrita săo os suportes e as ferramentas construídas para facilitar o retorno crítico a seu próprio texto6 $(\mathrm{DOLZ}, 2009$, p. 7).

6 Texto original em espanhol: “Uno de los procesos fundamentales de la enseñanza de la escritura consiste en releerse, revisar el texto de manera crítica y reescribirlo. Modificar la organización del texto adoptando um nuevo plan, introducir un nuevo párrafo, completar o desarrollar un argumento, reformular una frase, identificar un error gramatical, léxico u ortográfico para mejorar la primera versión del texto, han de formar parte del proceso de enseñanza. [...] Los alumnos tienen muchas dificultades para revisar y mejorar sus propios textos sin la ayuda del profesor. Una de las mayores novedades técnicas de la didáctica de la escritura son los soportes y las herramientas construidas para facilitar el retorno crítico a su propio texto". 
Sobre as ferramentas mediadoras do processo de revisăo/reescrita apontadas por Dolz (2009), na SDG analisada identificamos três modalidades diferentes: a revisâo coletiva mediada por slides com reproduçấo de textos de alunos com destaques de problemas (oficina 12); lista de constataçóes de características do gênero (de açăo, discursiva, linguístico-discursiva) usada na reescrita (oficina 12 e 13); correçáo do professor nos textos dos alunos (articulaçăo de diferentes tipos de correçăo: classificatória, indicativa, resolutiva e interativa) para mediar a reescrita individual (oficina 13). Essas ferramentas sâo muito importantes para o desenvolvimento das capacidades linguageiras do aprendiz.

Se observarmos o Quadro 4, voltados aos objetos linguístico-discursivos, notamos que somente os "modalizadores" e "conectivos" tiveram oficinas próprias para serem abordados. Na didatizaçăo de um gênero, é preciso fazer escolhas para transformá-lo em objeto de ensino. Em uma única SDG, é impossível abordar todas as possíveis dimensôes ensináveis de um gênero. A modelizaçăo se propóe justamente a fazer essa seleçăo, levando em conta, como vimos, os três princípios de validaçăo: legitimidade, pertinência e solidarizaçăo (DOLZ; GAGNON; DECÂNDIO, 2010). Sobre os modalizadores, já as comentamos anteriormente. No que diz respeito aos conectivos lógicos, foco do ensino na SDG, a legitimidade se faz evidente em qualquer observaçăo empírica de cartas do leitor; a pertinência ao contexto se deu pela observaçáo prévia de redaçóes dos alunos, que apresentavam grande dificuldade na mobilizaçâo de elementos coesivos sequenciais; a solidarizaçăo deu-se no conjunto da SDG - como a argumentaçâo foi destaque nas oficinas, náo havia como năo abordar os elementos coesivos voltados para a progressăo temática.

A modelizaçăo didática apontou como dimensăo ensinável a referenciaçăo à segunda pessoa do discurso (você) para se referir explicitamente ao leitor, assim como o uso de construçóes prescritivas para incitar o leitor a realizar uma açăo. Mesmo esse objeto năo sendo trabalhado em oficinas, desde a primeira produçăo os alunos, intuitivamente ou por imitaçâo dos textos presentificados na apresentaçăo da situaçăo, já utilizavam essa estratégia, como podemos perceber nesse fragmento: "Se você năo quiser mais seu bichinho doe-o ou procure um canil que tenha vaga" (carta: "Abandono de animais").

Pela análise, é possível verificar o caminho percorrido do modelo teórico para o modelo didático e para a didatizaçăo dos objetos na SDG. Como é possível constatar, a maioria das dimensôes ensináveis do gênero se tornaram alvo de ensino deliberado: em oficinas específicas para a sistematizaçăo de um objeto em particular, oficinas que articulam objetos diferentes (como as que comparam modalidades diversas de cartas), ou oficinas voltadas para a escrita, revisăo ou reescrita textual.

\section{CONSIDERAÇÕES FINAIS}

Este artigo debruçou-se sobre uma etapa importante do trabalho do professor: a transposiçăo didática externa7 do objeto de ensino - no caso analisado, a carta do

7 Embora, em alguns momentos da análise fatos da transposiçâo didática interna tenham sidos acionados, a transposiçâo externa foi o fio condutor da investigaçẫo. 
leitor. Entendemos que a modelizaçăo do objeto de ensino é uma ferramenta fundamental no planejamento das açôes didáticas. Ela permite ao professor selecionar o que se tem de mais relevante no objeto de referência para ser ensinado. Nesse processo, 0 contexto de ensino deve ser fruto de reflexóes, pois ele indica a pertinência dos objetos didáticos, os quais săo legitimados cientificamente pelo seu funcionamento empírico em situaçóes reais de uso.

Ao construirmos, no decorrer da nossa pesquisa, modelos teóricos dos gêneros dos Cadernos da Folha de Londrina, ${ }^{8}$ para, depois, pensarmos didaticamente na sua transposiçâo para o ensino, conseguimos, com mais propriedade, construir um modelo didático para o jornal escolar que estávamos idealizando (Jornal PIBID), bem como para seus gêneros. Isso mostra a relevância da modelizaçâo no planejamento didático.

Na nossa pesquisa, a sinopse da SDG mostrou-se também uma ferramenta fundamental no planejamento das açôes, visto que essa consegue organizar de forma sintética a sequência das atividades a serem desenvolvidas. Ela faz as vezes de um projeto, pois possibilita uma visualizaçăo geral da disposiçăo, hierarquizaçăo e sistematizaçấo dos diferentes objetos de ensino na SDG.

Sabemos que o projeto PIBID, pelo seu formato, permite um trabalho diferenciado; todavia, sem planejamento o trabalho se perde. Assim sendo, é essencial gastarmos mais tempo com açôes pré-intervençăo didáticas, como a modelizaçăo dos objetos e a planificaçăo de atividades, já que o objetivo maior do ensino, na perspectiva de documentos oficiais da educaçāo linguística (PCN - BRASIL, 1997, 1998; DCE - PARANÁ, 2008) é possibilitar ao aluno interagir por meio das linguagens em diversas situaçóes de comunicaçăo. Para tanto, é preciso um ensino mais processual e reflexivo do que quantitativo e burocrático.

Compreendemos também que năo basta um trabalho individual de planejamento e produçâa de materiais didáticos, pois isso se perderia com o passar dos anos. Cabe pensar em um ensino em espiral, no qual os conteúdos sejam trabalhados espiralmente, em graus de dificuldades variados.

Segundo Nascimento e Rosolem (2013, p. 14), “o polo do professor está sendo negligenciado". Segundo as autoras, isso acontece pois năo existe articulaçăo entre os sujeitos envolvidos na escola para a construçâo coletiva de materiais didáticos. Elas acreditam que essa interaçăo permitiria, entre outras coisas: desenvolvimento de pesquisas, troca de informaçóes, construçăo coletiva e permuta de materiais didáticos. Esse diálogo é justamente um dos grandes trunfos do PIBID, pois é um programa que viabiliza um trânsito fluido entre universidade e escola, formaçâo inicial e continuada, teoria e prática. No caso do subprojeto em questăo, a elaboraçăo de materiais didáticosSDGengloba uma rede de formaçăo e pesquisa cujos reflexos já se fazem sentir nos diferentes sujeitos a ela interligados: professor da universidade, alunos do curso de Letras, professores da Educaçăo Básica, alunos da Educaçâo Básica. 


\section{REFERÊNCIAS}

AEBY-DAGHÉ, S.; DOLZ, J. Des gestes didactiques fondateurs aux gestes spécifiques à l»enseignement-apprentissage du texte d»opinion. In: BUCHETON, D.; DEZUTTER, 0 . (Orgs.). Le développement des gestes professionnels dans l'enseignement du français: un défi pour la recherche et la formation. Bruxelas: De Boeck, 2008, pp. 83-105.

BARROS, E. M. D. Gestos de ensinar e de aprender gêneros textuais: a sequência didática como instrumento de mediaçăo. 2012. 359 f. Tese (Doutorado em Estudos da Linguagem) - Universidade Estadual de Londrina, Londrina, 2012a.

. Transposiçăo didática externa: a modelizaçăo do gênero na pesquisa colaborativa. Raído, Dourados, v. 6, n. 11, pp. 11-35, jan.-jun.- 2012b.

Memória das aprendizagens: um gesto docente integrador da sequência didática. Trabalhos em Linguística Aplicada, Campinas, n. 52, v. 1, pp. 107-126, jan.-jun. 2013.

Gesto didático de regulaçăo interna de cunho diagnóstico no procedimento "sequência didática de gêneros". Acta Scientiarum. Language and Culture, Maringá, v. 37, n. 4, pp. 335-346, out.-dez., 2015.

. MAFRA, G. M. Modelo teórico do caderno "Folha Cidades" da Folha de Londrina: ferramenta de transposiçăo didática. Revista Educaçăo e Linguagens, Campo Mourăo, v. 5, n. 8, pp. 38-60, jan.-jun. 2016.

BRASIL. Ministério da Educaçâo. Parâmetros curriculares nacionais: língua portuguesa (ensino de primeira à quarta série). Brasília/ DF: Secretaria de Educaçâo Fundamental, 1997.

Ministério da Educaçăo. Parâmetros Curriculares Nacionais: terceiro e quarto ciclos do Ensino Fundamental - Língua Portuguesa. Volume: Linguagens, códigos e suas tecnologias. Brasília: MEC/SEB, 1998.

BRONCKART, J-P. Atividade de linguagem, textos e discursos: por um interacionismo sociodiscursivo. Traduçăo: Anna Rachel Machado; Péricles Cunha. 2. reimpr. Săo Paulo: EDUC, 2003.

CARVALHO, T. E. M; GURGEL, E. A. Gêneros jornalísticos no ciberespaço: estudo sobre os portais UOL e G11. 2010. Disponível em: <http://www.intercom.org.br/papers/nacionais/2010/resumos/R5-0847-1.pdf>. Acesso em: 29 maio 2015.

CASTELlANI, R. A.; BARROS, E. M. D. Os gêneros do Primeiro Caderno da Folha de Londrina: a construçăo de um modelo teórico. Pesquisas em Discurso Pedagógico, n. 2, 2015. Disponível: <http://www.maxwell.vrac.puc-rio.br/rev_discurso.php?strSecao=input0>. Acesso em: 03 jan. 2016.

COSTA, S. G. Cartas de leitores gênero discursivo porta-voz de queixa, crítica e denúncia no jornal $O$ dia. Soletras: revista do departamento de letras da UERJ. Rio de Janeiro, $n$. 10, 2005. Disponível em: 〈http://www.filologia.org.br/soletras/10/03.pdf〉. Acesso em: 05 ago. 2014.

CORRÊA, S. A.; BARROS, E. M. D. Um estudo dos gêneros do Caderno Folha 2 da Folha de Londrina: primeira etapa da transposiçăo didática externa. Pesquisas em Discurso 
Pedagógico, n. 1, 2015. Disponível: <http://www.maxwell.vrac.puc-rio.br/rev_discurso. php?strSecao=input0>. Acesso em: 03 jan. 2016.

CÔRREA, Z. T. B. A carta do leitor.In: BONINI, A.; FERRETTI-SOARES, A. S.; JUNIOR, C. B.S.; WENDHAUSEN, V. (Orgs.). Os gêneros do jornal. Florianópolis: Insular, 2014. Coleçăo Linguística, v. 4.

COSTA-HÜBES, T. C.; SIMIONI, C. A. Sequência didática: uma proposta metodológica curricular de trabalho com os gêneros discursivos/textuais. In: BARROS, E. M. D.; RIOSREGISTRO, E. S. (Orgs.). Experiências com sequências didáticas de gêneros. Campinas: Pontes Editores, 2014. pp. 15-39.

CHEVALLARD, Y. La Transposition Didactique: Du Savoir Savant au Savoir Ensigné. Grenoble, La pensée Sauvage. 1991.

CRISTOVĂO, V. L. L. Aprendendo a planificar o próprio trabalho: gêneros textuais na formaçăo de professores de língua estrangeira. In: CRISTOVÂO, V. L. L.; NASCIMENTO, E. L. (Orgs.). Gêneros textuais: teorias e prática. Palmas e Uniăo da Vitória, PR: Kaygangue, 2005. v. 2

Modelo didático de gênero como instrumento para a formaçăo de professores.In: MEURER. J. L; Motta RUTH, D. (Orgs.). Gêneros textuais. Bauru/Săo Paulo: Edusc, 2001.

De PIETRO, J-F; SCHNEUWLY, B. O modelo didático do gênero: um conceito de engenharia didática.In: NASCIMENTO, E. L. Gêneros textuais: da didática das línguas aos objetos de ensino. Campinas: Pontes, 2014.

DOLZ, J. Claves para ensenar a escribir. Leer.es. Disponível em: <http://leer.es/documents/235507/242734/art_prof_ep_eso_clavesparaensenaraescribir_joaquimdolz. pdf/36f29ff9-193b-4d9b-b0b3-c8cf7c7bbc93>. Acesso em: 02 jun. 2010.

;GAGNON; R.; CANELAS-TREVISI; S. Cartes comcepttueles dês objets d"ensignement. In: SCHNEUWLY, B.; DOLZ, J. (Orgs.). Des objets em classe de français. Renes: Presses Universitaries Rennes, 2009, pp. 65-74.

; GAGNON, R.; DECÂNDIO, F. Produçáo escrita e dificuldades de aprendizagem. Campinas: Mercado das Letras, 2010.

; NOVERRAZ, M.; SCHNEUWLY, B. Sequências didáticas para o oral e escrito: apresentaçăo de um procedimento. Campinas: Mercado das Letras, 2004.

FRANCISCO FILHO, A. Gêneros Jornalísticos: notícias e cartas de leitor no Ensino Fundamental. Săo Paulo: Cortez, 2011.

GONÇALVES, A. V.; NASCIMENTO, E. L. Avaliaçăo formativa: autorregulaçăo e controle da textualizaçăo. Trabalho em Linguagem Aplicada, Campinas, v. 49, n. 1, pp. 241-257, jan.-jun. 2010.

MACHADO, A. R.; LOUSADA, E. G. A apropriaçăo de gêneros textuais pelo professor: em direçâo ao desenvolvimento pessoal e à evoluçăo do "métier". Linguagem em (Dis)curso, Palhoça, SC, v. 10, n. 3, pp. 619-633, set.-dez. 2010.

MELO, J. M. A opiniăo no jornalismo brasileiro. Petrópolis: Vozes, 1985.

NASCIMENTO, E. L. Práticas de letramento, gênero e interaçăo social: o saber e o fazer dos professores do ensino fundamental. In: COLÓQUIO INTERNACIONAL DE ESTUDOS 
LINGUÍSTICOS E LITERÁRIOS - CIELLI, 1. 2010, Maringá. Anais... Maringá: UEM/ PLE, 2010. Disponível em: 〈http://anais.cielli.com.br/artigos〉. Acesso em: 12 dez. 2010.

; ROSOLEM, L. D. D. L. O plano de trabalho docente: instrumento mediador no trabalho dos professores do paraná.In: CONALI, 4, 2013, Maringá. Anais...Congresso Nacional de Linguagens em Interaçăo (CONALI): Múltiplos Olhares. Maringá: UEM-PLE, 2013. v. 1, pp. 1-320.

PARANÁ. Secretaria da Educaçăo. Diretrizes Curriculares de Ensino do Paraná. Paraná: Governo do Paraná, 2008.

ROJO, R. H. R. Letramentos múltiplos, escola e inclusāo social. Săo Paulo: Parábola, 2009.

. Modelizaçăo didática e planejamento: duas práticas esquecidas do professor? In: KLEIMAN, A. (Org.). A formaçáo do professor: perspectivas da Linguística Aplicada, 2001.

SCHNEUWLY, B.; DOLZ, J. (Orgs.). Gêneros orais e escritos na escola. Campinas: Mercado de Letras, 2004a.

. Os gêneros escolares: das práticas de linguagem aos objetos de ensino. In: ; 71-91.

(Orgs.). Gêneros orais e escritos na escola. Campinas: Mercado de Letras, $200 \overline{4 b}$ p.

VIGOTSKI, L. S. Pensamento e Linguagem. 4. ed. Săo Paulo: Martins Fontes, 2008. 


\section{ANEXO A}

Cartas do leitor, publicadas na primeira ediçâo do Jornal PIBID.

\begin{tabular}{|c|c|c|}
\hline 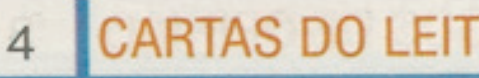 & JORNA & PIBID \\
\hline $\begin{array}{l}\text { O BRASIL NUNCA } \\
\text { SERÁ UM PAIS DE } \\
\text { PRIMEIRO MUNDO } \\
\text { Enquanto muito dinheiro foi gasto } \\
\text { com a Copa do mundo, com estádios } \\
\text { e panfletos de campanhas eleitorais, } \\
\text { muitos animais estão sofrendo nas } \\
\text { ruas. Muitos chegam até a morrer! } \\
\text { Todos os anos, cerca de dez mil an- } \\
\text { imais são abandonados nas ruas. Em } \\
\text { Lisboa, aproximadamente, sete ani- } \\
\text { mais chegam aos canis e apenas três } \\
\text { saem de lá com vida. Muitas vezes, } \\
\text { animais têm que ser abatidos, pois es- } \\
\text { tâo vegetando. No Brasil deveria ex- } \\
\text { istir práticas de adoção para animais } \\
\text { de rua. Vale dizer que o Brasil nun- } \\
\text { ca será um pais de primeiro mundo, } \\
\text { com animais morrendo nas ruas ou } \\
\text { com dinheiro sendo gasto com coisas } \\
\text { fúteis. } \\
\text { (Beatriz Assalin Picoloto, aluna do } \\
8^{*} A \text {, Colégio Monteiro Lobato). } \\
\text { O BRASIL NÃOÉ Ó PAis } \\
\text { DO FUTEBOL } \\
\text { A Copa do Mundo no Brasil foi um }\end{array}$ & 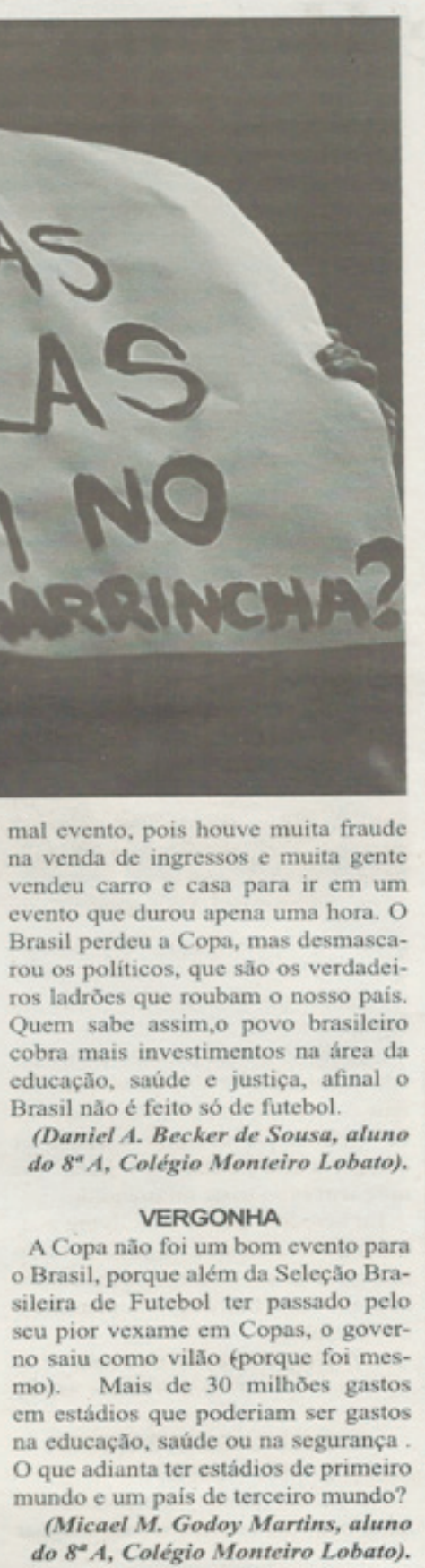 & 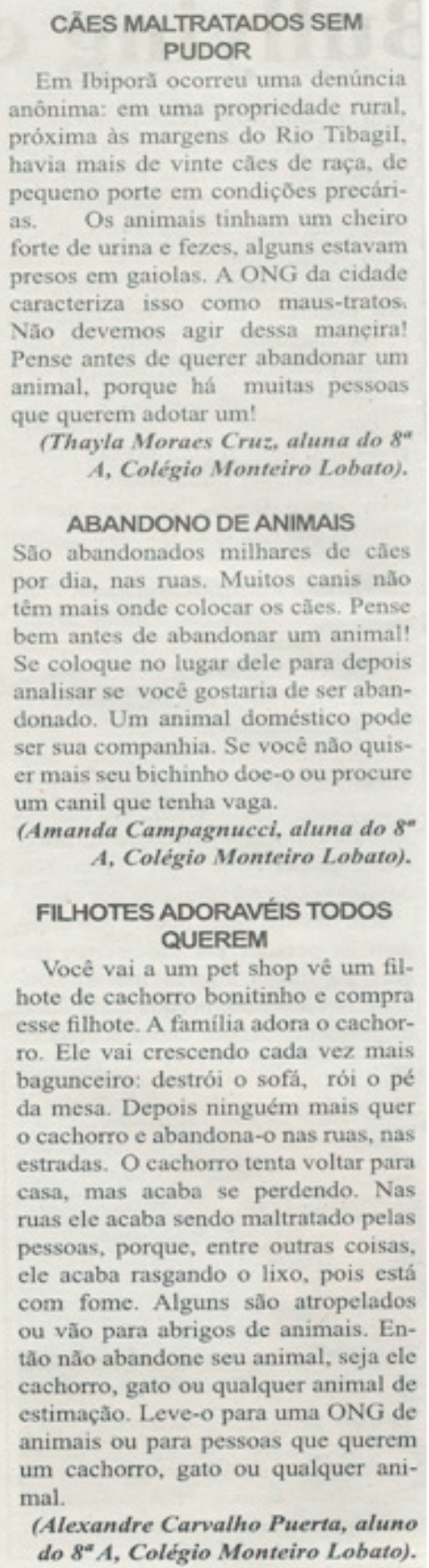 \\
\hline
\end{tabular}

Fonte: Jornal PIBID, 2014, p. 4 